\title{
How to Be a Domestic Goddess: \\ Female Film Stars and the Housewife Role in Postwar Japan
}

\author{
Jennifer Coates
}

How are mass publics persuaded to accept new gendered roles? The capacity of popular media to influence our understandings of the roles available and appropriate to us has proved a fascinating topic for researchers across a wide range of disciplines, and for academic and nonacademic writers alike. The case of early postwar Japan is particularly engaging in terms of this question because a booming popular press, rapidly increasing cinema attendance, and occupation censorship of mass media productions combined to create a complex nexus of factors that influenced popular understandings of how to be a

post-defeat Japanese citizen. Gendered roles were publicly scrutinized as Allied occupation agendas clashed with grassroots understandings of gendered performance. Mass media productions were co-opted into the project of reforming the roles and identities available to the Japanese public during the early years of the occupation (1945-52). The Japanese cinema and its surrounding print media generated alternately seductive and disciplining affects (emotions or desires) around these new gendered roles.

The role of full-time professional housewife was not only one of the more highprofile roles under discussion in the popular press of the postwar era but continues to inform how Japanese home life is understood, both domestically and internationally, today. This role has been imagined alternately as an import from the United States, as a continuation of the gendered behavior of Japan's recent past, and as a modern way of living in the new highrise housing developments (danchi) that visually confirmed Japan's postwar rebuilding.

Jennifer Coates is an Assistant Professor in the Hakubi Center for Advanced Research, hosted by the Graduate School of Letters at Kyoto University. She was awarded a Ph.D. in 2014 from the School of Oriental and African Studies, University of London. She is the author of Making Icons: Repetition and the Female Image in Japanese Cinema, 1945-1964 (Hong Kong University Press, 2016). 
As Hiroko Hirakawa has observed, middle-class, full-time professional housewives are "elite minorities in Japanese society, yet politicians, bureaucrats, conservative intellectuals, business leaders, and the mass media have portrayed them as the prototypical inhabitants of postwar Japan."1 The widespread assumption that a significant number of full-time professional housewives existed in postwar Japan is apparent in the extensive media coverage of the role, peaking in the "Housewife Debate" (shufu ronsō) ${ }^{2}$ conducted in Fujin kôron (Women's Review) magazine beginning in 1955. These discussions focused on the beneficial and detrimental aspects of the housewife role for female development and for Japanese society more generally, although the actual existence of significant numbers of full-time housewives in everyday life went unquestioned. How did the housewife become such a persuasive construct? Responding to this question, this essay explores the representation of female film stars as housewives in the film journals and fan magazines of the early occupation era, to suggest that the Japanese mass media, and particularly its star system, played a part in situating the full-time professional housewife as a normative female role in postwar Japan.

Many historians have noted the persuasive influence of publications aimed at the adult female demographic, especially with respect to desirable or acceptable roles for women. ${ }^{3}$

Discourse on the full-time professional housewife at the center of the nuclear family was particularly charged in the early postwar era, in part due to popular understanding of the role as having been newly imported from the United States. Throughout this essay, such claims are treated as discursive techniques rather than historical fact; the Japanese family structure, like the family imagined elsewhere in the world, has continued to develop and change throughout history. Furthermore, popular understandings of the desirable or "normal" in relation to the family rarely reflect the full diversity of how we live. This essay focuses on one aspect of this issue, exploring how an imagined gendered role was made to seem understandable, attractive, and even inevitable for the mass public of postwar Japan. All further references to ideas of the family, tradition, and normality are made with this in mind: namely, that such concepts are discursively constructed and maintained, and distinct from lived everyday experiences.

Andrew Gordon suggests that the "reality gap" between media treatment of gendered roles and everyday experiences is evident in both pre- and postwar Japan in relation to the housewife. ${ }^{4}$ In the context of formalized initiatives to "rationalize" the home and standardize the role of the housewife, which were central to the New Life Movement, he questions how women became "ready" to hear the message of the movement. ${ }^{5}$ What 
kinds of media sources laid the groundwork for conceptualizing the full-time housewife role in the early occupation era, and how was the popular imagination of the housewife constructed at this stage? Broadening out from the approach of previous studies, which focus on lifestyle magazines aimed at a female readership, this essay analyzes the representation of female film stars in film and fan magazines of the occupation era to reveal the simultaneously seductive and disciplining affects involved in crafting and normalizing the postwar housewife role.

Conceptually if not always in practice, gendered roles and identities changed rapidly in postwar Japan under the Allied occupation. At the same time, cinema attendance increased at great speed, ${ }^{6}$ and critics discussed the new types of gender roles showcased on the screen in a booming popular-press culture. While the occupation headquarters identified the cinema as a key tool for the reeducation of the Japanese populace, particularly where gender equality was concerned, many female film stars appear to have struggled with the professional housewife role. As a discursive construct, the idealized professional housewife worked only in the home, whereas the actresses who portrayed housewives on screen worked very much in the public sphere. Film journals and fan magazines reflected this dichotomy, juxtaposing accounts of studio visits and interviews in the stars' workplace with features on female stars' homes and personal relationships. A brief outline of the development of the postwar housewife role, along with a short account of how star personae were constructed in the Japanese studio system of the early postwar era, precedes the analysis below of how female stars, as both working women and homemakers, were presented to the public. This analysis is intended to demonstrate how the housewife role was presented to the reading and viewing public both as an attractive aspirational ideal and as a disciplining normative construct.

\section{Introducing the Postwar Housewife: The Japanese Family under the Occupation} During the Allied occupation, the General Headquarters of the Supreme Commander of the Allied Powers (hereafter SCAP GHQ) engineered a set of social reforms designed to fundamentally change everyday life in Japan. Although the inclusion of provisions for gender equality in Articles 14 and $24^{7}$ of the 1947 Constitution of Japan is often discussed today as the occupation forces' legacy, Christine de Matos argues that "gender reform was not a priority of the architects of the Occupation, but was rather an afterthought in the wider reform program, or perhaps subsumed beneath the more amorphous labels of democratization and human rights." ${ }^{8}$ Furthermore, many of these reforms are now 
acknowledged to have been incompletely assimilated into everyday life, ${ }^{9}$ and the destabilization of gender roles occasioned by wartime conscription and reliance on female labor suggests that Japanese activists and lawmakers would perhaps have achieved universal suffrage without the intervention of SCAP.

Trends toward the adoption of a nuclear family structure were also evident during the prewar period as a consequence of industrialization. Subsequently, wartime Japan experienced the breakup of many traditionally structured families due to the loss of spouses and parents both at home and overseas during Japan's Fifteen Years War (1930-45). The three-generation Japanese family of the ie system had been disrupted long before the intervention of the occupation administration. In this respect, as in many others, we cannot interpret the early postwar era as a complete break with prewar and wartime history.

In popular discourse, although not always in practice, the American-style nuclear family replaced the Neo-Confucian-based $i e$ family structure in which three generations of relatives lived under one roof, typically cared for by the mother and later by the daughterin-law. ${ }^{10} \mathrm{~A}$ boom in suburban living, encouraged by the new danchi housing complexes, later cemented the idea of the modern Japanese family as a small nuclear structure built around a home-based female parent and wife. The centrality of, and distinctions between, these domestic roles for women were debated in popular media as well as academic discourse. Vera Mackie argues that the modern housewife became "the archetypal figure of womanhood" in the early postwar period. ${ }^{11}$

Language also played a part in suturing together past and present concepts of the housewife, as popular discourse on this new type of female role fused terminology such as katei fujin, or "at-home wife," with the older shufu, originally a designation for the main wife or head wife of the women's quarters in families that included multiple wives and concubines. ${ }^{12}$ The reference to managing or organizing other family members implicit in the concept of shufu reflects the managerial aspects of the postwar housewife role, which involved managing not only household funds but also the rest and refueling of other family members on their return home from outside work or schooling. ${ }^{13}$ The housewife's responsibilities thus extended to managing the human resources necessary for capitalist production in off-duty periods. However, postwar usage of the term shufu can also be attributed in part to the circulation of English-language home-management manuals. For example, the term shufu reentered common parlance through Japanese translations of introductory textbooks on the role of the Anglo-American housewife. ${ }^{14}$ Since the wives 
of occupation personnel often tutored their Japanese domestic helpers in the American, Australian, or British way of running a home, ${ }^{15}$ the postwar shufu was associated with Anglo-American and outsider influence despite her premodern etymology.

The intensity of early postwar discourse on the housewife, her nominal designation, era and area of origin, and historicization, belies the relative scarcity of real-life examples of the full-time professional housewife in occupation-era Japan. Kathleen Uno suggests that full-time wives who did not work outside the home were rare, existing only among the upper sections of the new urban middle classes. ${ }^{16}$ This is supported by Joanna Liddle and Sachiko Nakajima's findings that the predominant image of the Japanese woman as the fulltime "professional housewife" is negated by abundant evidence of women's participation in the employment field. ${ }^{17}$ This discrepancy between discourse and demographics highlights the aspirational aspect of the image of the woman in the home, a point Sheldon Garon attributes to pre- and postwar "mass circulation housewives magazines," which popularized the concept of the full-time housewife as the "norm" and at the same time articulated the lifestyle in terms of "dreams." ${ }^{18}$ Film magazines participated in this association of the housewife with aspirational living, presenting luxury homes and high fashion in the context of stars' domestic roles.

SCAP propaganda participated in the construction of such desirable images of postwar democratic living by placing the romantic union of the worker husband and housewife at the center of the family, in an effort to destabilize elements of the ie system that were perceived as feudal, particularly those which privileged parent-child relations. Producers of films, books, and magazines were encouraged to depict young men and women choosing their marriage partners freely, and forming modern nuclear families centered on egalitarian romance. However, studies of actual conditions within the postwar Japanese family indicate that SCAP's reforms penetrated only so far. Investigating for UNESCO in 1961, Koyama Takeshi found that many young couples continued to accept arranged marriages, and that relations between husband and wife remained unequal. ${ }^{19}$ Yet mass media censors and writers alike were invested in presenting popular film stars as idealized modern housewives. Film magazines relied on the seductive glamour of the stars to keep readers' interest and custom, while censors were guided by SCAP HQ's directive to use the cinema and its surrounding media to present postwar Japan as the occupiers believed it should be, rather than as it was. Both bodies participated in the idealization of the star housewife. 


\section{The Japanese Cinema under Occupation}

The representative potential of the cinema to normalize the postwar situation and provide a pattern for how to live did not escape SCAP HQ. The "Memorandum Concerning Elimination of Japanese Government Control of the Motion Picture Industry," circulated as early as October 16, 1945, indicated that the Japanese film industry was to play an important role in the nation's recovery. According to Kitamura Hiroshi's reading of the document, the cinema was imagined as a means to "educate" and "reorient" Japanese viewers. ${ }^{20}$ Censors would request changes and deletions in synopses and screenplays prior to censoring or suppressing final film prints. Trade and fan magazines were similarly restricted in their reporting on the film industry and its stars.

Kitamura argues that occupation censorship was explicitly designed to encourage changes in Japanese attitudes and beliefs through mass media. According to Marlene Mayo, the Civil Information and Education Section of the offices of SCAP (hereafter CIE) had even attempted to formulate a hypothetical typical Japanese viewer, known as "Moe-san," to anticipate potential reactions to media texts. Based on their understanding of wartime schooling and social indoctrination, the CIE attempted to predict Moe-san's

reaction to the media of the postwar period, with the intention of influencing the ideal viewer's "democratization" through this same media. ${ }^{21}$ In this way, SCAP's political use of the studios in the post-defeat era drew heavily on wartime practices, as the CIE utilized censorship practices similar to those of wartime. Postwar star personae within the major studios were similarly constructed from the prewar and wartime personae of individual stars, in order to capitalize on extant viewer interest and create a pleasurable nostalgic affect for filmgoers. These star personae were then incorporated into SCAP-mandated film narratives, characterizations, and imagery.

One significant change in postwar cinema relative to prewar content was the number and type of roles available to female actresses. According to Kyoko Hirano, David Conde, head of the Motion Picture and Theatrical branch of the CIE until July 1946, encouraged studios, film journals, and gossip magazines to present a positive image of newly democratic Japan, and specifically of women in the public eye. Conde instructed filmmakers to avoid confining female characters to domestic familial roles, "considering their newly upgraded social status," 22 and studios and scriptwriters were encouraged to produce narratives that depicted emancipated Japanese women as aspirational icons. This essay builds on Hirano, Kitamura, and Mayo's analysis of SCAP documentation relating to the cinema by analyzing the language of early postwar film 
magazines to suggest how the predominantly male critics, writers, and editors of the era may have contributed to the popular understanding of the housewife role through critical discussion of female star personae.

Competitive overproduction among the major studios and increasing numbers of roles for women, particularly younger women and teenage girls, created a demand for new female stars, which resulted in a public recruitment drive known as the "New Faces" (ny $\bar{u}$ feiisu). Both the influx of new stars and the language of the gossip magazines suggest a shift in modes of public consumption of film stars in postwar Japan. Unlike prewar stars, the "New Faces" were received as public property. This could be explained in part by the fact that most of these young actresses were scouted from the ranks of the Takarazuka Opera or from smaller revue shows and cabarets, so that many of them had a popular following before their reincarnation as film stars. Fan magazines became ever more intimate with these new stars, following them home and quizzing them on their marital status and romantic aspirations. Although SCAP HQ handed censorship responsibilities over to the Control Committee for the Motion Picture Code of Ethics (renamed the Film Ethics Regulation Control Committee and popularly known as Eirin) on April 14, 1949, the large number of new female stars ensured that female roles would continue to dominate in film content and discourse until the end of the occupation.

\section{The Japanese Studio Star System}

Kitamura's account of how SCAP came to recognize the power of cinema to influence public attitudes may be explained in part by the attraction of the star persona and its relevance to the everyday lives of film fans. Until Hideaki Fujiki's Making Personas: Transnational Film Stardom in Modern Japan (2013), however, the construction of star personae in the Japanese studio system had not been systematically explored. Scholars of Japanese cinema tended to treat star personae as a self-explanatory phenomenon, ${ }^{23}$ or to draw from Richard Dyer's work on star personae in the golden age of Hollywood. Since the Japanese studio system mirrored Hollywood in many ways, Dyer's work is not a bad fit, describing the star persona as a hybrid construction influenced by both artistic and industry-specific factors:

The star phenomenon consists of everything that is publically available about stars. A film star's image is not just his or her films, but the promotion of those films and of the star through pin-ups, public appearances, studio handouts and so on, as well as interviews, biographies and coverage in the press of the star's doings and 
"private" life. Further, a star's image is also what people say or write about him or her, as critics or commentators. ${ }^{24}$

Fujiki's description of the Japanese star system in the 1910s and 1920s suggests that in the early years of the Japanese star system, as actors began to supersede film narrators (benshi) as the focus of audience interest, a distinction emerged between American and Japanese stars. Japanese stars were not associated with their on-screen roles, whereas American stars were assumed to be similar in personality to the characters they played. By the 1920s, however, audiences had also begun to conflate Japanese stars with film characters, to the extent that stars began to attempt to create clearer distinctions between their "real" personae and their previous roles. ${ }^{25}$ Interviews published in popular magazines provided a means to clarify the star persona. As a dedicated print-media industry grew up around the cinema, the Japanese star persona was increasingly informed by the external factors described by Dyer above.

Although Fujiki's study is confined to the first decades of Japanese cinema, postwar criticism and fan writing indicates that his analysis holds for the post-defeat era also. Writing in Kinema junpō (Film Record, a.k.a. The Movie Times) in 1948, film critic Iida Shinbi describes the construction of the postwar Japanese star persona in terms of the factors described by Fujiki and Dyer. Iida acknowledges that "from a commercial perspective (eiri), stars are very important," echoing Fujiki's observation that the film star system (sutā shisutemu) is similar to the earlier theater version. Iida emphasizes the factors other than specific performances that build a star persona, noting that "star's lives (seimei) and the story of how they were discovered (hakkensareru koto) are central to creating a star." 26

Iida's account of the postwar Japanese star system connects this popular interest in stars' backgrounds and home lives to the affects they invite. He argues that stars channel affect through visual properties: "human instinct" (ningen no honno) responds to a "beautiful face and figure" by producing a sense of "longing" (akogare). ${ }^{27}$ Iida's argument is very similar to Nigel Thrift's association of star glamour with positive affect, where engaging with a star persona becomes a kind of "consumer capitalism," "part of a series of overlapping affects." ${ }^{28}$ Dyer similarly links the star persona to postwar capitalism, as "stars play out some of the ways that work is lived in a capitalist society." 29

Although the housewife's life on screen was often an enviably privileged one, the female stars who took housewife roles in the early postwar tsuma-mono, or "housewife 
films," nevertheless played out the everyday physical tasks of housework on film. In contrast, stars are rarely shown performing menial tasks in the popular print media detailing their off-screen lives. Although the accounts of home life cited below touch on issues such as boredom, they maintain the glamorous affect designed to produce longing for the star and her lifestyle. This seductive quality of the star persona may encourage the viewer or reader to aspire to the star's life. In the flattering language used to describe the star housewife in film magazines, the fan is encouraged to aspire to the star's idealized home life rather than to her more difficult on-screen performances.

However, the female star was constructed not only as an aspirational figure but also as an accessible one. Film critics managed this dualism by subtly separating the star's performance and her imagined real life. Iida argues that stars "should seem close to the viewer; enjoyable viewing is tied to the lowest general viewer's preferences" (kansho gan no hikui ippan kankyaku no konomi to musubitsuite).$^{30}$ Critics and fans wrote approvingly in the popular press of stars who appeared to be accessible, such as Tanaka Kinuyo (1909-77), and disapprovingly of those who did not, such as Hara Setsuko (1920-2015). Eiga bunko (Film Library) reports that film fans imagined Tanaka as familiar and "close to themselves" (midikana hito), ${ }^{31}$ whereas viewers complained that Hara was "hard to get any feeling from." ${ }^{32}$ At the same time, however, Hara's onscreen performances as dutiful housewife and daughter characters were generally praised, while Tanaka's were often described as inscrutable. ${ }^{33}$ The second part of this essay analyzes how the difficult balance between glamour and intimacy was negotiated in accounts of stars' home lives and housework, and how the star was positioned as an aspirational or disciplining example for the reader.

\section{Star Housewives: Women and the Home in Popular Film Magazines}

Female stars appeared in relation to the home and the housewife role in a variety of contexts in the film magazines of the early postwar era. Discourse on stars and their relation to the housewife role generally took place in the magazines directed at fans and female readers, rather than in trade publications or those dealing with aesthetic critique and philosophical or technical issues. Journals such as Kinema junpō, Eiga geijutsu (Film Art), and Eiga hyōron (Film Criticism) tended toward auteur-focused critical analysis and industry news, with occasional issues dedicated to the structure of the star system or theoretical topics related to star personae. The star was a generalized concept rather than an individual in these discussions, and if named, tended to be male. In contrast, fan magazines such as 
Eiga fan (Film Fan), Eiga goraku (Film Entertainment), and Eiga bunko focused largely on female stars - their personal style, love stories, and struggles. This second group of magazines was most concerned with the star housewife, and often presented star interviews or gossip as learning material for the reader. Viewers were advised on how to dress or act like a particular star, both in the home and the workplace. The articles discussed below are taken from this group of publications between 1945 and 1950.

\section{Introducing the Star Housewife: The Home Visit}

In controlled interviews organized by the film studio to which the star was contracted, journalists were invited to interview or observe the star in her home. These features were juxtaposed with on-set interviews and reportage that showed the star at work; in contrast, features on the star at home presented an opportunity to show another side of her persona. For this reason, these articles featured new stars, or established stars who had undergone some change in personal circumstance, and were presented in terms of getting to know the star better, establishing an intimate connection with her, or seeing her private side. For example, ex-child-star Takamine Mieko (1918-90) took interviewers on a tour of her home to demonstrate how her star persona had developed from cute girl to refined woman. The large pictures of her tasteful home published in Eiga fan in 1949 emphasized her aesthetic qualities, including a portrait of Takamine in kimono, sitting demurely in her tatami mat room..$^{34}$

The kind of intimate affect afforded by the home-visit interview had a clear impact on stars' popularity. Takamine's appeal was explicitly linked to her personal life, in that critics claimed she had become more popular after marriage. ${ }^{35}$ The home-visit feature drew attention to this most popular aspect of her persona, while also emphasizing her beauty, refinement, and dress sense in her choice of kimono and home furnishings. ${ }^{36}$ She was described as a "longed-for" (akogare no sutā) and "sympathetic" star (kyōkan o yobaseru $s u t \bar{a}$ ), credited with the power to "transmit her happiness directly to the audience" (sono yorokobi wa wareware kankyaku ni chokketsushita mono de aru). ${ }^{37}$ Emphasizing the home-based aspects of her persona rather than her work at once brought her readership closer to the part of her persona imagined as her "real life" and reflexively imbued the reader's own home life with some star glamour. The positioning of Takamine as "refined" or "admirable" (yukashiku) $)^{38}$ encouraged the viewer to emulate her in such aspects as dress and home design, bringing the pursuit of housewifely perfection closer to the pursuit of star glamour. 
While Takamine used the home visit to draw attention to the more popular aspects of her star persona, troubled stars such as Miura Michiko (1917-69) attempted to use the format to correct issues in the perception of their star persona. Generally described as somewhat fast, loose, or impulsive, Miura invited Eiga fan to her home after her sudden marriage in 1946 to discuss her new conjugal life. She emphasized her housewifely role, telling the anonymous interviewer that home life was her priority: "I work as much as I can before the household duties become heavy" (ima no uchi dekiru dake shigoto o shite). ${ }^{39}$ This attempt at domesticity was short-lived, as she later divorced and moved to the United States to marry an American soldier, returning to Japan to pursue small roles to "mixed reviews." ${ }^{40}$ Miura was unable to shake off her fast reputation, finding roles as street-walking sex-worker characters in films such as Naruse Mikio's White Beast (Shiroi yaju, 1950$)$. Although temporarily aligning her persona with the housewife role did not lead to sustained popularity for Miura, it is nonetheless pertinent that the actress (and perhaps her studio) viewed this as a means to appeal to viewers.

At-home interviews were both aspirational and disciplining, for they posited the domestic space as luxurious and private on the one hand, yet insisted on the star's responsibility to open this space to the reader on the other. In the physical space of the home and the rhetorical space of the interview, the housewife star was expected to meet the interviewer-as-guest's every demand. Female stars who avoided the housewife role, such as Hara Setsuko, limited writers to interviewing them either in their work spaces or in public leisure spaces. Hara's insistence on maintaining a distance from the popular press may have contributed to the public's perception of her as a cold albeit glamorous star, a view that was compounded by her sudden disappearance from the Japanese screen after 1963. Although several high-profile stars were able to maintain careers and fan bases despite censorious commentary in film and gossip magazines, the sharp tone of such commentary nonetheless suggests that it may have had a disciplining impact on a readership keen to observe the stars as models for everyday life.

Almost any association of star and housewife role appeared to invite a home visit; one interviewer even took this so far as to visit the home of a newly married male star. "Popular Star as a Husband: Record of a Visit to the Star's Wife" (Ninki sutā o otto ni moteba; sutā no okusan hōmonki) focused on the domestic arrangements of Sano Shūji, though the actor himself is notably absent from most of the article. Instead, the anonymous interviewer reviews the wife's role as hostess, noting appreciatively that she greeted his arrival with the formal "Welcome!" (Irasshaimase!), and took great care of the couple's 
young son during the interviewer's time as her guest. ${ }^{41}$ Two recurring motifs are apparent in this kind of feature: that the housewife is expected to be always accessible, always on duty; and that the star housewife is doubly accessible because both her professions, within and outside the home, require her to make herself available to others.

\section{Creating the "Good" Housewife through Discourse: The Gossip Column}

The second common format for articles on star housewives was the gossip column. The content of these articles can be surprising, given the context of strict censorship; rumors of failed marriages were common, and while the tone was often judgmental, actresses deemed unlucky in love were afforded an element of sympathy despite non-normative home circumstances. A two-part feature in Eiga bunko in 1947 entitled "Love Is Beautiful: Stars and Marriage" (Ai wa uruwashi: sutā to kekkon) demonstrates how news of stars' love lives and home lives was transmitted to viewers in alternately aspirational and disciplining ways.

Excepting Uehara Ken (1909-91), all the stars featured in the "Love Is Beautiful" series are female. Each star is positioned as an example of a particular kind of romance; despite the title's claim, many subsections relate tales of heartbreak, sorrow, and even

death. A common theme is the extent of the female star's willingness to quit her job to become a housewife: those who did so succeeded in love, whereas those who did not failed miserably (although it is notable that, like Miura above, even stars depicted as failing in love often enjoyed long careers). The feature begins with the cautionary tale of Kuwano Michiko (1915-46), who fell ill on an unhappy film shoot and quickly died. Although she had a young daughter, she "worked hard at her job" (shigoto ni amari muri o shite) and "in part due to this" (anna koto ni natta no desu) could not keep in good health. ${ }^{42}$ Kuwano's unwillingness to quit her job to care for her child is implied to have resulted in nothing less than her death, suggesting that blindly pursuing career objectives at the expense of the family will have tragic results.

In another feature, refusal to accept one's place in the home is related through the metaphor of blindness, which was also a common device in wider popular discourse. Todoroki Yukiko (1917-67) is introduced with the subtitle "Grasping Love in an Era of Blindness" (shitsumei jidai ni tsukanda ai) ${ }^{43}$ After a disastrous love affair with Kataoka Chiezo (1903-83), she married Makino Masahiro (1908-93) in Nagoya in 1940, and by 1947 they had a one-year-old son. Todoroki's "era of blindness" initially appears to refer to her ill-fated affair with Kataoka, although the anonymous author also hints that 
all may not be well in the Makino-Todoroki marriage. Emphasizing that Todoroki is still working outside the home, the author notes that Makino refers to Todoroki as "my wife, a woman like the 'rose-colored glasses' of Yoshibē" (uchi no nyōbō wa "nonki megane" Yoshibe mitai na onna da yo). ${ }^{44}$ His use of the old-fashioned "nyōbō" and reference to "rose-colored glasses" suggest a contented domestic life, but a deeper reading uncovers a darker theme. Rose-Colored Glasses (Nonki megane) was a popular 1937 novel by Ozaki Kazuo, who would later publish The Story of Yoshibe (Yoshibè monogatari, 1953). Ozaki's autobiographical narrative features a man living in poverty with a new wife and newborn daughter in a chaotic home. Yoshibē, a diminutive of the common name Yoshie, is closely modeled on Ozaki's second wife. She is described as "so amusing, so jubilant," "bursting with child-like energy," and is the catalyst for her older husband engaging with the world, muse to his creative impulse. ${ }^{45}$ Yet Yoshibē is also subjected to domestic violence and verbal abuse in Ozaki's novel, and the protagonist paints her as tiresome and impulsive. Readers of "Grasping Love" may thus have inferred that Todoroki was blind to a similar impending disaster in her marriage to Makino, and sure enough, the two separated in 1950.

Stars were rarely reported as declaring an explicit aversion to home life; rather, those with more impulsive or independent star personae were depicted as tragically unsuited to life as a housewife. Yamada Isuzu (1917-2012), one of Japanese cinema's most prolific actresses, is described in these terms; after the birth of her child, she took a break from work and devoted herself to the home, but "it came to feel like a cold wind was blowing through her home life" (katei seikatsu ni wa dandan tsumetai kaze ga fukisusabu yō ni). ${ }^{46}$ Although she asked herself "how could she warm up her home," her husband came home drunk each night, and their married life and home life collapsed (kekkon seikatsu wa ie no hakyoku ni oiyarareta). ${ }^{47}$ Although Yamada is described as having made every effort to conform to the ideal wife-and-mother image, her marriage ended in disaster and her husband's family adopted her child against her wishes, leaving her "in terrible isolation" (kodoku no mi to natta). On the failure of her second marriage, the writer suggests sharply that perhaps Yamada was "not a person who can be a housewife" (ikka no shufu toshite seikatsu dekiru hito de wa nai). ${ }^{48}$ Stars who did not make a success of their housewife roles were presented as deficient or lacking in some personal quality, although in Yamada's case this did not affect her popularity.

The disciplining function of this line of argument is more explicit in the second installment of the series, published a month later, in November 1947. Immediately under the title "Love Is Beautiful: Stars and Marriage 2" is the following, in large type: "Actresses 
are also women, after all. If they marry, they can become splendid housewives and mothers of family homes" (Joyū mo yahari josei de aru. Kekkon sureba, rippa na katei no shufu ni mo nari, hahaoya ni mo naru no de aru) ${ }^{49}$ In associating the perceived womanly nature of actresses with the role of housewife and mother, this claim implies that these roles are the natural occupations for women, particularly in the use of "after all" (yahari). Building on this theme, a refusal to recognize the imagined "natural" allocation of home-based labor to women is articulated as somehow immature. The anonymous writer argues:

\footnotetext{
Unmarried actresses say, "My job is my lover, it's my husband" ("Watashi wa shigoto ga aijin, otto desu wa" to kekkonshinai joȳu o iu). But actresses are also women, and when they get married it's natural (tōzen) that they leave the world of filmmaking and become housewives (katei fujin); really, not one in ten actresses would want to devote her whole life to film (hontō ni isshō o eiga ni sasageru joȳu wa jū nin ni hitori mo nai no de aru).
}

Not only are readers encouraged to think of the housewife role as "natural" for women, but the writer's claim that actresses would prefer to retire to take care of their homes and families, rather than continue working, performs a second rhetorical move using the seductive qualities of the star system. If a glamorous film star would rather be a housewife than an actress, of course women working outside the film industry should not think twice before giving up a boring office or factory job to work at home! Through its association with film stars, the housewife role is situated as a glamorous alternative to work in the public sphere, even as those stars themselves achieved their fame and glamour through work in that very public arena. This logical fallacy was, however, obscured by the allure of glamour on the one hand, and by the threat of disaster intimated by the cautionary tales that surround the writer's claims on the other.

Balancing inspirational tales with cautionary episodes, the anonymous writer weaves a picture of self-sacrifice for the home as a means for women to win approval, appreciation, and even future opportunity. Citing the "old example" of Takasugi Sanae (1918-95), who married Ichikawa Danjirō the Third during the war, the writer suggests the value of sacrificing career goals early. Takasugi was "at the height of her popularity" (ninki no zeccho no koro) when she married, so when she retired, "exceeding regret was expressed from all quarters" (kakuhō men kara hijō ni oshimareta).$^{50}$ She "gave up her showy screen life" (hanayakana sukurīn seikatsu ni ketsubetsushita) to mother three children, but the writer implies that this was all worthwhile, noting approvingly that "just 
last year she began discussions to reenter the film world." Takasugi pursued a long career after her reappearance in 1948, suggesting that star housewives may also have been early examples of the postwar "M-curve" created by women leaving the workforce for marriage and then returning when their children are older or independent (although in Takasugi's case the eldest would have been only around ten years old).

Actresses returning from a period of housework were generally well spoken of by critics and gossip writers; in fact, the more willing to become a housewife an actress had appeared to be, the more celebrated she was upon her return to the screen. Miyake Kuniko (1916-92), "an intellectual actress" (chisei no joyū) with many fans, stopped working even before she married, quitting on the day her marriage plans were decided. Eiga bunko commented admiringly that "such actresses are rare" (mezurashii), and observed after her comeback, "While young people don't know her, for middle-aged viewers she hasn't changed at all. It's quite nostalgic" (natsukashii). ${ }^{51}$ Initial compliance with gendered domestic expectations appears to have increased the likelihood of a positive response from critics and gossip writers. The irony of this situation, in which willingness to give up work is rewarded with a kinder assessment of one's work later on, in many ways reflects the double bind in which many women find themselves, balancing the counterintuitive demands of work and home life.

In this respect the female star became a kind of "everywoman" as well as a glamorous icon. Actresses who had retired were referred to consistently as "housewives," using the terms katei fujin, katei shufu, and shufu, although when the word "home," or $k a t e i$, appears, the addition of adjectives such as "splendid" (rippa) reminds the reader that the star's home and life are much more glamorous than her own. Shufu appears to have been a relatively aspirational term in itself, rarely qualified by descriptive adjectives. The etymology of shufu as a mainstay of domestic life $\mathrm{e}^{52}$ chimes with the terms shujinkō and shuyaku used to describe the main film roles played by major stars. In this sense, the female star is indeed a larger-than-life version of the housewife. It is also significant that most of the stars mentioned at this early stage in the postwar era began their careers during or before the war. In casting prewar and wartime stars as examples of the postwar ideal housewife, writers sutured the housewife role into an imagined historical continuity, balancing the glamour of the new or westernized aspects of the postwar housewife role with a sense of tradition.

The persuasive language of Eiga bunko's "Love Is Beautiful: Stars and Marriage" disciplines as well as seduces to create the impression of the housewife as the postwar 
Japanese woman's natural role. While Yamaji Fumiko, Higashiyama Mitsuko, Yaguchi Yōko, Katō Teruko, Enami Kazuko, and Kasuga Eiko were among the major stars who settled uncomplainingly into housewife roles (katei no shufu ni osamatte shimatta), ${ }^{53}$ the article reports that those who attempted to keep working met with difficulty. The writer implies that an unwillingness to become a full-time housewife is related to lack of success at work, describing how Enami Kazuko and Togawa Yumiko both married around the same time, but whereas Enami retired immediately, Togawa attempted to continue her career (sono ato o nagaku joyū seikatsu o tsudzukete ita). "Her good reputation gradually disappeared, and she retired unnoticed to become a homemaker" (amari kanbashiku naku, itsu no ma ni ka katei no hito to natta). ${ }^{54}$ In refusing Togawa the aspirational shufu, referring to her instead with the less glamorous and less feminine katei no hito, the writer implies that she has missed her chance to become a true housewife by handling her retirement ungracefully. Actresses who returned to work "too quickly" were judged similarly harshly. For example, Kusajima Kyōko had retired after her marriage, but "appeared again recently in [Mizoguchi Kenji's 1946 film] Five Women around Utamaro (Utamaro o meguru gonin no onna) showing none of her old charm (mukashi no miryoku wa nai)." ${ }^{55}$ Although many actresses continued long successful careers after marriage, the writer's insistence on retirement as the only option for married women mirrors the studios' own policies of encouraging women to quit work after marriage. ${ }^{56}$

These bleak examples of nonconformism are swept away at the end of "Stars and Marriage" with the happy example of Ōhara Eiko, who "stepped back from filmmaking when she saw her chance at marriage, and now relishes the life of a housewife" (shufu seikatsu o ajiwatte iru). The writer concludes, "From the examples lined up here, we can understand that in any event, if an actress marries, she can settle into a happy housewife's life" ( $k \bar{o}$ narabete iru to, joyū mo yahari kekkon sureba, kōfukuna katei fujin to natte osamatte iru koto ga wakaru). ${ }^{57}$ Yet it does not seem clear that this was the case "in any event" (yahari), as the examples of Yamada and Togawa show. However, what does emerge from a close reading of the presentation of female stars in relation to the home throughout the early years of the occupation is the fact that, then as now, many widespread and conflicting opinions as to appropriate and fulfilling roles for women were voiced stridently in the public sphere.

As women in the public eye, actresses were judged particularly harshly, with voices from all quarters weighing in on their life choices. Actresses are professional women working outside the home to portray a range of female roles and experiences, which 
necessarily include roles inside the home. In this sense, the way the public is encouraged to negotiate the figure of the actress exposes a condition common to female experience more generally, in that women's multiple roles, commitments, and affinities can challenge or endanger one another. Proficiency in the role of the housewife necessitates removing oneself from work in the public sphere, while proficiency as an actress necessitates being able to portray the role of the housewife. The stay-at-home aspect of the professional housewife role means that one cannot experience proficiency as a housewife and as an actress simultaneously. In the early postwar era, however, one actress tried to "have it all" by using the star system to mediate her dual roles of film star and housewife.

\section{The Star Housewife as Advocate for Home Life}

In 1947, popular character actress Kogure Michiyo (1918-90) became embroiled in the housewife star discussion when the Eiga bunko gossip column "Star Record" (Sutā toroku) inquired into her home life arrangements. Describing Kogure as a "housewife and mother," the anonymous columnist expressed pseudo-concern about balancing these roles with her career as an actress. "As a housewife and mother, how does she keep up home life and her life as an actress without failing in either?" (Katei no shufu de ari, ko no haha de aru kanajo ga, katei seikatsu to joyū seikatsu to o ika ni hatan naku ikinukō ka). ${ }^{58}$ Kogure was hailed as a style icon by women and as something of a sex symbol by male critics and viewers, who appreciated the "sex appeal" (iroke) of her lively kimono-clad roles. ${ }^{59}$ As we can see from the examples above, however, even popular actresses could become the target of gossip related to negative perceptions of their domestic arrangements and offscreen lives. As though recognizing the centrality of her off-screen life to the maintenance of her star persona, Kogure attempted to align her on-screen and off-screen personae.

Beginning in February 1949, Kogure wrote a small personal advice column in Eiga fan entitled "The Key to My Life as a Housewife" (Watashi no shufu seikatsu no hiketsu). A head and shoulders portrait of Kogure in kimono introduces the column; she smiles gently out at the reader, tilting her head as though listening. Although Eiga fan ran regular features on star style and female fashion, the magazine was not explicitly directed at women readers. Kogure, however, addresses her reader not only as a woman but also as a housewife or future housewife. And despite her reported protestations that her vampy, heavy-drinking on-screen characters were far from her real persona, ${ }^{60}$ Kogure's advice is crafted to support certain aspects of her on-screen star persona created by screwball roles such as that of Umetaro, the friendly local geisha of Blue Mountains (Aoi sanmyaku, Imai 
Tadashi, 1949). In keeping with such on-screen performances, Kogure encourages her readers to blend feminine softness with lighthearted play:

You should lovingly depend on your husband (otto ni amaeru) and make use of
women's gentle nature (yasashisa) to make harmony in the home. Getting a little
silly in the home is the secret to housewife life, I think (ie no naka de wa dekiru
dake baka ni natte iru koto ga shufu seikatsu no hiketsu de wa nai ka to omoimasu).
When I'm alone in the house, I like to do childish, foolish things (baka), like play
"Catch the ball."You should take time apart from your husband sometimes (tokidoki
otto to hanareru). We are separated due to work, so thanks to this every day is like a
honeymoon (shinkon)! Housewife life keeps you in beautiful health (shufu seikatsu
wa utsukushiku kenkō). ${ }^{61}$

Kogure's account of her home life mirrors her on-screen persona in its inclusion of anecdotes such as the one about the game of "Catch the ball," repeating a playful action she was often seen performing on film. This would have made it easy for the reader to imagine Kogure at home, because she presents her visual image and actions as consistent with her on-screen performances. Her appeal to women's "gentle nature" also positions the reader, imagined as female, in the same category as Kogure; as women, both were imagined to share this quality. Positioning the reader in intimate relation to the star in this way would have been highly seductive, as the glamour of Kogure's persona was reflected onto the reader by way of her claim to their shared experience. This intimate affect is fostered by phrases such as "when I'm alone" and "the key [or secret, hiketsu] to my life," which imply that the reader is a privileged observer of the private aspects of Kogure's life. The reader's ability to imagine Kogure at home could create a sense of familiarity that encouraged warm sympathetic feeling toward the actress and an enjoyable sense of inclusion for the reader.

Kogure's column aimed to persuade the reader of the value of homemaking through this appeal to glamour, intimacy, and playfulness. At the same time, the column performs a disciplining function similar to that of the gossip columns described above, in two ways. Although Kogure addresses the reader as a fellow housewife, she also speaks from a position of authority, both as a famous and wealthy star and as an advice columnist. While her description of "getting a little silly" and "taking time apart" would appear to acknowledge a need for relief from the pressures of the home, she nonetheless makes the standard association between housework and women's "natural" abilities in her advice 
to readers to use their "gentle nature" to make the home harmonious. Devoting oneself to making the home a nurturing space for others is positioned as beneficial to the housewife in return, in the claim that "housework keeps you in beautiful health."

The second disciplining aspect of Kogure's column occurs at the level of the construction and maintenance of the star persona. Regular readers of fan magazines and film journals were not shielded from the more constructed aspects of the world of film because articles on set visits, costuming and makeup techniques, and the scouting of new stars gave a frank description of the behind-the-scenes life of the cinema. Iida Shinbi's article described above even explicitly outlines how the star persona is constructed, albeit for the slightly different readership of Kinema junpō. It is therefore reasonable to expect that many film fans would have been aware of the constructed nature of the star persona, and negotiations of the star image would have been recognizable to them as attempts to improve or reshape the star persona. As an implicit response to articles questioning Kogure's ability to manage home and work life "without failing in either," her column sends the clear message that women were expected to defend themselves against such aspersions by emphasizing the centrality of housework to their lives. Kogure downplays her non-household-related work in her column (although the column itself is an example of this kind of work), referencing outside employment only in positive relation to her home life; being apart during working hours is credited (sono okage de) with improving her marital relationship. Yet Kogure obfuscates the fact that both she and her husband work outside the home, making it possible for the reader to interpret her advice within the context of an idealized full-time professional housewife waiting for her husband to return home. In this way, the female reader was implicitly encouraged to behave as though housework was her whole work experience, even where this was not the case.

Kogure's repositioning of her star persona was highly successful; as electrical goods companies began to target the housewife as a prime customer demographic, Sanyo Electric hired her to be "Mrs. Sanyo," in an advertising strategy that emphasized the connection between the "use of household electrical appliances and an American way of life" beginning in $1955 .{ }^{62}$ Kogure's reward for her successful performance of housewifely devotion was, paradoxically, more offers of work outside the home. In light of the social impact of the star persona, her example can be understood as a model for women, encouraging a kind of rhetorical flexibility in which women who worked outside the home were encouraged to view their domestic roles as their primary identifications, even if equal or more time was spent on outside work. In this sense, Kogure'star persona 
is an example of the distinction between "social practice" and "social discourse" described by Ofra Goldstein-Gidoni, who argues that the full-time professional housewife is "more dominant in the latter than the former." ${ }^{93}$

Through the representation of star housewives in popular media, we can see the early beginnings of how "representations of advertising and the popular media (magazines, television and film) directed women's lives into the interior spaces of the urban nuclear unit," as Sandra Buckley argues of the 1960s and 1970s, using the very images and personae of women who worked outside the home. ${ }^{64}$ Addressing how desire for the imagined professional housewife role was produced even among women who did not have the economic or social means to perform such a role exclusively supports Jan Bardsley's argument that desire for a particular kind of lifestyle or experience is a "socially and historically contingent phenomenon." ${ }^{65}$ Acknowledging the contradictions at the heart of popular imaginaries of the full-time professional housewife in this way sheds some light on how the conditions were created in which the 1955 "Housewife Debate" took place.

\section{Conclusion: The "Full-Time Professional Housewife" as Imagined Norm}

As Uno, Garon, Liddle and Nakajima, and many others have shown, the postwar full-time professional housewife was an aspirational identity rather than everyday experience for many women, at least until the national prosperity of the later 1950s, 1960s, and 1970s. My analysis of the representation of female film stars demonstrates how the housewife role was constructed and presented as simultaneously desirable and normative, aspirational and inevitable. The discursive strategies outlined in this essay were not restricted to early post-defeat film and gossip magazines, however, but continued into the mass media of the post-postwar. For example, Bardsley's account of the 1955 "Housewife Debate" in Fujin kōron shows the writers who sparked the debate performing a discursive maneuver similar to that of the stars, interviewers, and columnists discussed above-namely, presenting themselves as unremarkable housewives and obscuring their personal histories of education, travel, and political experience.

Ishigaki Ayako, who began the debate with her scathing article "The Secondary Occupation Called the Housewife" in the February 1955 issue of Fujin kōron entitled "A Special Issue Devoted to Working Women," made no mention of her long period living in the U.S., where she met and married the artist Ishigaki Eitarō, a member of Greenwich Village intellectual community in the 1930 s. ${ }^{66}$ Similarly, Sakanishi Shio, responding to Ishigaki in "The Blindspots in "The Secondary Occupation Called the Housewife" in 
April 1955, obscured her scholarly background and doctorate from the University of Michigan, presenting herself as an "ordinary housewife" (heibon na katei no shufu). ${ }^{67}$ Both the language and the rhetorical style of these articles are strikingly similar to those of the star housewife discussion in the popular print media of the early occupation era. By outlining the factors that influenced this early discourse-from occupation censorship and the seductive and disciplining affects of the star system to the often-competing desires of individual working actresses and writers-I have suggested one way in which the background of the 1955 debate was formed.

When the willful suspension of disbelief encouraged by the cinema and star system was combined with the glamorous attraction of the star persona and the disciplining affect of the gossip-oriented publication industry, the identity of the full-time housewife became very persuasive even in the face of real-life outside-work commitments and experiences. In this way, the mass media participated in the creation of the full-time housewife identity, persuading the Japanese public to accept this role as a real-life phenomenon in the same way that we consume the clearly fictionalized star persona as a real-life event.

\section{Acknowledgments}

I'd like to thank Nozomi Matsuyama for her thoughtful proofreading, and my two reviewers for their significant contributions.

\section{Works Cited}

Anon. "Ai wa uruwashi: sutā to kekkon" (Love is beautiful: Stars and marriage). Eiga bunko 2 (October 1947): 51-56.

Anon. "Ai wa uruwashi: sutā to kekkon 2" (Love is beautiful: Stars and marriage 2). Eiga bunko 3 (November 1947): 30-33.

Anon. "Ninki sutā o otto ni moteba: sutā no okusan hōmonki" (Popular star as a husband: Record of a visit to the star's wife). Eiga fan 7, no. 7 (July 1947): 26.

Anon. "Otona no renai eiga o omou" (On films about adult love). Eiga fan 6, no. 4 (September 1946): 4-5.

Anon. "Shizen no utsukushiisa: Hara Setsuko san" (A natural beauty: Hara Setsuko). Eiga fan 9, no. 2 (February 1949): 8-9.

Anon. "Sutā tōroku" (Star record). Eiga bunko 1 (September 1947): 34- 36.

Anon. "Sutā tōroku" (Star record). Eiga bunko 3 (November 1947): 14-15.

Anon. “Takemine Hideko.” Eiga bunko 2 (October 1947): 15.

Bardsley, Jan. "Discourse on Women in Postwar Japan: The Housewife Debate of 1955." U.S.Japan Women's Journal, no. 16 (1999): 3-47.

"What Women Want: Fujin Kōron Tells All in 1956." U.S.-Japan Women's Journal, no. 19 (2000): 7-48. 
Buckley, Sandra. "Altered States: The Body Politics of 'Being-Woman."' In Andrew Gordon, ed., Postwar Japan as History, 347-72. Berkeley, Los Angeles, and London: The University of California Press, 1993.

de Matos, Christine. "A Very Gendered Occupation: Australian Women as 'Conquerors' and 'Liberators."' U.S.-Japan Women's Journal, no. 33 (2007): 87-107.

Dyer, Richard. Heavenly Bodies: Film Stars and Society. London and New York: Routledge, 2004.

Freiberg, Freda. "Genre and Gender in World War II Japanese Feature Film: 'China Night' (1940)." Historical Journal of Film, Radio and Television 12, no. 3 (1992): 245-52.

Fujiki, Hideaki. Making Personas: Transnational Film Stardom in Modern Japan. Boston: Harvard Yenching Institute Monograph Series, 2013.

Garon, Sheldon. "State and Family in Modern Japan: A Historical Perspective." Economy and Society 39, no. 3 (2010): 317-36.

Gerteis, Chris. Gender Struggles: Wage Earning Women and Male-Dominated Unions in Postwar Japan. London: Harvard University Press, 2009.

Goldstein-Gidoni, Ofra. Housewives of Japan: An Ethnography of Real Lives and Consumerized Domesticity. London: Palgrave Macmillan, 2012.

Gordon, Andrew. "Consumption, Leisure and the Middle Class in Transwar Japan." Social Science Japan Journal 10, no. 1 (2007): 1-21.

- "Managing the Japanese Household: The New Life Movement in Postwar Japan." Social Politics (Summer 1997): 245-83.

Hane, Mikiso. Eastern Phoenix: Japan Since 1945. Oxford: Westview Press, 1996.

Harada Noboru. "Ninki sutā no kazukazu" (Various popular stars). Eiga bunko 3 (November 1947): 34-39.

Hirakawa, Hiroko. "The Politics of Gender and Mass Media in Post-1975 Japan: Its Implications for 'Us."' U.S.-Japan Women's Journal, no. 19 (2000): 49-82.

Hirano, Kyoko. Mr. Smith Goes to Tokyo: Japanese Cinema under the American Occupation, 1945-1952. London and Washington, D.C.: Smithsonian Institution Press, 1992.

Iida Shinbi. "Sutā no kei jiki" (The star phenomenon). Kinema junpō 39 (August 1, 1948): 2.

Imai, Yasuko. "The Emergence of the Japanese Shufu: Why a Shufu Is More Than a Housewife." U.S.-Japan Women's Journal, English Supplement, no. 6 (1994): 44-65.

Izbicki, Joanne. "Scorched Cityscapes and Silver Screens: Negotiating Defeat and Democracy through Cinema in Occupied Japan.” Ph.D. diss., Cornell University, 1997.

Kitamura, Hiroshi. Screening Enlightenment: Hollywood and the Cultural Reconstruction of Defeated Japan. Ithaca, N.Y., and London: Cornell University Press, 2010.

Kogure Michiyo. "Watashi no shufu seikatsu no hiketsu" (The key to my life as a housewife). Eiga fan 9, no. 2 (February 1949): 33.

Koyama, Takeshi. The Changing Social Position of Women in Japan. Paris: UNESCO, 1961.

Liddle, Joanna, and Sachiko Nakajima. Rising Suns, Rising Daughters: Gender, Class and Power in Japan, London and New York: Zed Books, 2000.

Mackie, Vera. Feminism in Modern Japan: Citizenship, Embodiment and Sexuality. Cambridge: Cambridge University Press, 2003. 
Matsubara Ichirō. "Iroke to joyū" (Actresses and sex appeal). Eiga goraku 2, no. 2 (April 1948): 13.

Mayo, Marlene. "Civil Censorship and Media Control in Early Occupied Japan: From Minimum to Stringent Surveillance.” In Robert Wolfe, ed., Americans as Proconsuls: United State Military Government 1944-1952, 263-320. Carbondale: Southern Illinois University Press, 1984.

Ohinata, Masami. "The Mystique of Motherhood: A Key to Understanding Social Change and Family Problems in Japan.” In Kumiko Fujimura-Fanselow and Atsuko Kameda, eds., Japanese Women: New Feminist Perspectives on the Past, Present and Future, 199-212. New York: The Feminist Press at The City University of New York, 1995.

Ozaki, Kazuo. Rosy Glasses and Other Stories. Trans. Robert Epp. Kent: Paul Newbury Publications, 1988.

Sanada Shiini. "Yukashiku utsukushiku; Takamine Mieko" (A distinguished beauty: Takamine Mieko). Eiga fan 9, no. 2 (February 1949): 6-7.

Satō Tadao and Yoshida Chieo. Nihon eiga joyushi (History of Japanese actresses). Tokyo: Haga shoten, 1975.

Thrift, Nigel. "Understanding the Material Practices of Glamour." In Melissa Gregg and Gregory J. Seigworth, eds., The Affect Theory Reader, 289-308. Durham, N.C., and London: Duke University Press, 2010.

Tsukamoto Jirō. "Dare ka ichiban oshare ka?" (Who is the most stylish?). Eiga bunko 2 (October 1947): 42-44.

Tsurumi, Kazuko. Social Change and the Individual: Japan Before and After Defeat in World War II. Princeton, N.J.: Princeton University Press, 1970.

Uno, Kathleen S. "The Death of 'Good Wife, Wise Mother"?" In Andrew Gordon, ed., Postwar Japan as History, 293-322. Berkeley, Los Angeles, and Oxford: University of California Press, 1993.

Yasuda Sumio. "Kaze no naka no mendori” (Hen in the wind). Eiga hyōron 5, no. 12 (1948): 39-40.

Yoshimi, Shunya. “'Made in Japan': The Cultural Politics of 'Home Electrification' in Postwar Japan." Media, Culture and Society 21: 149-71.

\section{Notes}

1. Hirakawa, "The Politics of Gender and Mass Media in Post-1975 Japan," 52.

2. Bardsley, "Discourse on Women in Postwar Japan."

3. Bardsley, "What Women Want"; Garon, "State and Family in Modern Japan," 331.

4. Gordon, "Consumption, Leisure and the Middle Class in Transwar Japan," 5.

5. Gordon, "Managing the Japanese Household," 269.

6. Ticket sales increased by 34 percent between 1945 and 1946. Audience attendance was calculated at 733 million (rounded to the nearest million) in 1946, increasing to surpass one billion in 1957. The number of cinema theaters peaked at 7,457 in 1960. See Izbicki, "Scorched Cityscapes and Silver Screens," 46.

7. http://japan.kantei.go.jp/constitution_and_government_of_japan/constitution_e.html 
8. de Matos, "A Very Gendered Occupation," 89.

9. Koyama, The Changing Social Position of Women in Japan, 45; Hane, Eastern Phoenix, 33.

10. Many families, particularly in the countryside, continue to live as three generations under one roof. Popular discourse on changes to the Japanese family structure, and loss of Japanese tradition, tended to focus on the developments within cities and suburbs. However, there remain great differences in both lifestyle and attitude between rural and urban areas. See Tsurumi, Social Change and the Individual, 229.

11. Mackie, Feminism in Modern Japan, 123.

12. Imai, "The Emergence of the Japanese Shufu," 47.

13. Ohinata, "The Mystique of Motherhood," 203.

14. Imai, "The Emergence of the Japanese Shufu," 57.

15. de Matos, "A Very Gendered Occupation."

16. Uno, "The Death of 'Good Wife, Wise Mother'?," 303.

17. Liddle and Nakajima, Rising Suns, Rising Daughters, 175.

18. Garon, "State and Family in Modern Japan," 331.

19. Koyama, The Changing Social Position of Women in Japan, 45, 54.

20. Kitamura, Screening Enlightenment, 42.

21. Mayo, "Civil Censorship and Media Control in Early Occupied Japan," 303.

22. Hirano, Mr. Smith Goes to Tokyo, 149.

23. Freiberg, "Genre and Gender in World War II Japanese Feature Film," 245.

24. Dyer, Heavenly Bodies, 2-3.

25. Fujiki, Making Personas, 185.

26. Iida, "Sutā no kei jiki," 2.

27. Ibid.

28. Thrift, "Understanding the Material Practices of Glamour," 308.

29. Dyer, Heavenly Bodies, 6.

30. Iida, "Sutā no kei jiki," 2.

31. Anon., "Sutā tōroku," Eiga bunko 1, 34.

32. Anon., "Shizen no utsukushiisa," 9.

33. Yasuda, "Kaze no naka no mendori," 39.

34. Sanada, "Yukashiku utsukushiku," 6-7.

35. Yasuda, "Kaze no naka no mendori," 35.

36. Anon., "Takemine Hideko," 15; Tsukamoto, "Dare ka ichiban oshare ka?," 42.

37. Sanada, "Yukashiku utsukushiku," 7.

38. Ibid.

39. Anon., "Otona no renai eiga o omou," 4.

40. Satō and Yoshida, Nihon eiga joyushi, 205.

41. Anon., "Ninki sutā o otto ni moteba," 26.

42. Anon., "Ai wa uruwashi," Eiga bunko 2, 53.

43. Ibid., 53-54. 
44. Ibid., 53.

45. Ozaki, Rosy Glasses and Other Stories, 112.

46. Anon., “Ai wa uruwashi," Eiga bunko 2, 55.

47. Ibid.

48. Ibid.

49. Anon, "Ai wa uruwashi," Eiga bunko 3, 30.

50. Ibid.

51. Ibid.

52. Imai, "The Emergence of the Japanese Shufu," 47.

53. Anon., "Ai wa uruwashi," Eiga bunko 3, 31.

54. Ibid., 32.

55. Ibid.

56. Gerteis, Gender Struggles, 39.

57. Ibid.

58. Anon., "Sutā tōroku," Eiga bunko 3, 15.

59. Matsubara, "Iroke to joyū," 13.

60. Anon., "Sutā tōroku," Eiga bunko 3, 14-15.

61. Kogure, "Watashi no shufu seikatsu no hiketsu," 33.

62. Yoshimi, "Made in Japan," 158.

63. Goldstein-Gidoni, Housewives of Japan, 41.

64. Buckley, "Altered States," 352.

65. Bardsley, "What Women Want," 21.

66. Bardsley, "Discourse on Women in Postwar Japan," 11.

67. Ibid. 